\title{
Kapasitas Kelembagaan Pengelola Desa Wisata Brajan Kabupaten Sleman
}

\author{
Clara Shinta Paskasari ${ }^{1}$, Budi Guntoro ${ }^{2}$, Roso Witjaksono ${ }^{3}$ \\ Affiliation \\ 1,2,3Program Studi Magister Penyuluhan dan Komunikasi Pembangunan, \\ Sekolah Pascasarjana, Universitas Gadjah Mada
}

\section{Correspondence}

Clara Shinta Paskasari. Program Studi Magister Penyuluhan dan Komunikasi

Pembangunan, Sekolah Pascasarjana, Universitas Gadjah Mada. Jl. Teknika Utara, Pogung Kidul, Sinduadi, Kec. Mlati, Kabupaten Sleman, Daerah Istimewa Yogyakarta 55281. Email: shintapaskasari@gmail.com/ clara.shinta.p@mail.ugm.ac.id

\begin{abstract}
Tourism is a rapidly growing sector in Indonesia in recent years. Tourism development is now also moving to villages by raising local wisdom in each place. Brajan is one of the Tourism Villages in Sleman Regency which is included in the growing category. This village is interesting to share because it has great potential and offers a more varied compared to supported villages. One indicator in determining village classification is in terms of capacity of its managers. For this reason, a study was conducted to see the capacity of managers in Brajan to take part in the strategies taken to improve it. The study was conducted qualitatively with data collection methods in the form of interviews, observation, and documentation. Informants in the interview were managers of tourist villages, youth, and the community. The aim is to map institutional capacity. Organizational capacity will be seen from managerial aspects, resource management, and participation. The results of this study indicate that managerial does not have the ability to manage programs and processes, but in terms of relationship management and collaboration is good. In terms of managing resources, both human resources and infrastructure, financial and technological resources are still lacking. Participation is still lacking because many managers are already inactive.
\end{abstract}

Keywords: Institutional capacity; Village tourism; Brajan village; Sleman.

Article Information

Submitted 29 July 2019 | Revised 23 January 2020 | Accepted 28 August 2020

Recommended Citation: Paskasari, C. S., Guntoro, B., and Witjaksono, R. (2020). Kapasitas Kelembagaan Pengelola Desa Wisata Brajan Kabupaten Sleman. Jurnal Pariwisata Terapan, 4(1), 12-24. https://doi.org/10.22146/jpt.48259 


\section{Pendahuluan}

Salah satu jenis pariwisata yang banyak berkembang di Kabupaten Sleman adalah desa wisata. Beberapa desa wisata di Kabupaten Sleman sudah berkembang pesat dan bahkan sudah menjalin kerjasama dengan berbagai pihak eksternal. Meskipun demikian, masih terdapat desa wisata yang mengalami mati suri karena keterbatasan yang ada. Saat ini sudah ada 38 desa wisata yang tersebar di seluruh Kabupaten Sleman. Dari jumlah tersebut baru 9 desa wisata yang masuk di dalam kategori desa wisata mandiri, dan 9 yang masuk kategori desa wisata berkembang, sisanya masuk dalam kategori desa wisata tumbuh. Adapun kriteria dalam menentukan klasifikasi desa wisata dilihat dari beberapa indikator yaitu:

1. Potensi atraksi

2. Kapasitas manajerial pengelola

3. Peran serta masyarakat

4. Sarana dan prasarana

5. Kepemilikan aset

6. Aksesibilitas

7. Pemasaran dan promosi

Setelah dinilai berdasarkan pada indikator di atas maka kemudian dikelompokkan menjadi sebagaimana tertera dalam Tabel 1.

Tabel 1. Klasifikasi Desa Wisata di Kabupaten Sleman

\begin{tabular}{ll}
\hline \multicolumn{1}{c}{ Klasifikasi } & \multicolumn{1}{c}{ Nama Desa } \\
\hline Tumbuh & Bokesan, Brajan, Pajangan, Kadisobo, Kaliurang Timur, Mlangi, Gondang, \\
& Sangubanyu, Pancoh, Dukuh Pandowo, Palgading, Temon Pandowo, Dalem \\
& Widodomartani, Trumpon, Gabugan, Garongan, Nganggring, Nawung, \\
& Malangan, Sendari, Ledoknongko, Ngamboh \\
Berkembang & Gamplong, Turgo, Plempoh, Rumah Domes, Ketingan, Tunggul Arum, Sambi, \\
& Sukunan, Mangunan \\
Mandiri & Kelor, Kembangarum, Pentingsari, Srowolan, Brayut, Sidoakur Jethak II, \\
& Tanjung, Pulesari, Grogol \\
\hline & (Sumber: Dinas Pariwisata Kabupaten Sleman, 2015)
\end{tabular}

Merujuk pada tabel 1, maka pembinaan desa wisata di Kabupaten Sleman masih perlu dilakukan karena sebagian besar desa wisata di Kabupaten masih masuk dalam kategori tumbuh. Maka diperlukan kerjasama dari berbagai pihak dalam melakukan pengelolaan desa wisata yang tersebar di Kabupaten Sleman. Pengelolaan desa wisata yang baik tentu akan berkorelasi positif pula pada kunjungan wisatawan. Dari Dinas Pariwisata Kabupaten Sleman bisa memberikan pendampingan dari segi pengembangan destinasi, pengembangan industri, pengembangan pemasaran, dan struktur kelembagaan. Empat aspek tersebut merupakan aspek yang esensial dalam pengembangan desa wisata. Pengembangan destinasi diperlukan agar keunggulan yang ditawarkan dapat dikelola dengan baik dan memiliki produk yang bisa diunggulkan. Produk unggulan inilah yang akan menjadi daya tarik utama dari desa wisata tersebut.

Di Kecamatan Minggir khususnya, terdapat sebuah desa wisata bernama Dusun Brajan. Desa wisata Brajan adalah sebuah desa yang memiliki keunggulan hasil kerajinan bambu. Desa wisata ini terletak di sisi Barat Kabupaten Sleman tepatnya di Kecamatan Minggir. 
Berdasarkan Laporan Statistik Kepariwisataan DIY yang disusun oleh Dinas Pariwisata Provinsi Daerah Istimewa Yogyakarta Tahun 2016 tercatat sebanyak 1.008 pengunjung yang seluruhnya berasal dari wisatawan nusantara telah berkunjung ke lokasi ini. Namun berdasarkan data kunjungan tersebut hanya berlangsung dari Januari sampai April saja, selebihnya tidak tercatat jumlah wisatawannya. Kunjungan tersebut sebagian besar berasal dari kunjungan kelompok meskipun ada pula beberapa kunjungan perorangan. Pada tahun 2017 sampai Bulan Oktober sebagaimana dipublikasikan di website yang beralamat di http://www.bambubrajan.com ada beberapa kelompok yang sudah melakukan wisata ke Brajan di antaranya rombongan dari SD Pangudi Luhur Surakarta, PNPM Mandiri Kabupaten Gresik, dan dari Kelompok Pengrajin Paliyan Gunung Kidul.

Sebagai sebuah desa wisata, keunggulan yang ditawarkan oleh Dusun Brajan adalah industri kerajinan bambunya yang dikerjakan oleh sebagian besar masyarakat desa dan telah menjadi komoditas ekspor yang menjanjikan. Pengelolaan desa wisata sebelumnya berada di bawah kepengurusan pedukuhan namun akhirnya dibentuk kelompok pengelola. Pembentukan kelompok pengelola ini dapat mempermudah koordinasi dan lebih fokus dalam pengembangan desa wisata. Meskipun pembentukan kelompok pengelola ini dapat dikatakan terlambat namun ini merupakan sebuah kemajuan bagi pengelola desa wisata. Nantinya kelompok ini akan menjadi motor penggerak desa agar dapat berkembang menjadi desa wisata mandiri.

Keberadaan sebuah kelembagaan khusus yang menangani pengelolaan desa wisata sebenarnya merupakan hal yang penting. Apalagi kapasitas manajerial dari pengelola desa wisata juga merupakan sebuah aspek yang dinilai oleh Pemerintah Kabupaten Sleman dalam mengklasifikasikan desa wisata. Hal ini dikarenakan di dalam kegiatan pariwisata maka akan ada kegiatan-kegiatan krusial misalnya kegiatan promosi, penerimaan tamu, perawatan sarana prasarana, pengembangan, dan lain-lain. Kementerian Pariwisata pada tahun 2012 telah menerbitkan sebuah buku berjudul "Pedoman Kelompok Sadar Wisata". Berdirinya kelompok sadar wisata ini merupakan upaya pemerintah untuk melibatkan masyarakatnya di dalam kegiatan pariwisata sehingga dapat berlangsung sebuah pemberdayaan masyarakat. Sadar wisata dalam hal ini berarti masyarakat harus memiliki kesadaran untuk berperan aktif dalam menjalankan kegiatan pariwisata yaitu kesadaran untuk menyadari peran dan tanggung jawabnya sebagai host atau tuan rumah dan kesadaran tentang hak dan kebutuhannya untuk menjadi pelaku wisata.

Di Desa Wisata Brajan, kelompok pengelola sudah ada dan berjalan meskipun belum berbentuk Kelompok Sadar Wisata. Pengelola desa wisata di Brajan sebenarnya memiliki modal yang besar karena selain kerajinan bambu, ada beberapa potensi wisata yang dapat ditawarkan dari Desa Wisata ini yaitu kesenian Kuntulan, Karawitan, dan Campursari. Selain itu panorama alam di desa ini juga mendukung dengan kondisi alam yang didominasi oleh persawahan. Untuk akses dari pusat kota Yogyakarta juga relatif mudah dan jalanan sudah halus. Apalagi dari pihak padukuhan memberikan dukungan penuh. Didukung pula oleh tren pariwisata yang terus meningkat dari tahun ke tahun karena kemudahan promosi yang memanfaatkan teknologi. Untuk sumber daya manusia pun memadai karena pemuda setempat cukup aktif dalam memberikan sumbangan ide maupun bantuan dalam pengelolaan desa wisata. Ide-ide brilian pemuda inilah yang dapat dijadikan input kebijakan dalam pengelolaan. Selain itu dari perangkat pemerintahan juga sudah cukup peduli dengan 
keterlibatan perangkat padukuhan dalam menjalankan usaha desa wisata dan juga peran dari pemerintah desa yang memberikan bantuan infrastruktur melalui dana desa. Potensi dan faktor-faktor pendukung tersebut sebenarnya sudah cukup mumpuni untuk menjadikan Desa Wisata Brajan ini sebagai sebuah destinasi desa wisata unggulan.

Namun pada kenyataannya Desa Wisata Brajan belum dapat berkembang sebagaimana desa wisata yang lain. Sebagai desa wisata berkategori tumbuh, kehidupan wisata di Brajan terus mengalami pasang dan surut dalam jumlah pengunjung. Jika dilihat secara administratif, sudah sejak tahun 2017 tidak tercatat adanya jumlah kunjungan wisatawan yang dilaporkan pada laporan tahunan Statistik Kepariwisataan Provinsi Daerah Istimewa Yogyakarta. Hal ini mengindikasikan proses administrasi yang kurang baik di Desa Wisata Brajan. Pengembangan pariwisata di Brajan sangat perlu dilakukan karena desa ini bukan satu-satunya desa wisata yang menawarkan keunggulan berupa wisata kerajinan bambu. Selain itu secara kelembagaan juga belum terlaksana dengan baik meskipun struktur organisasi sudah ada. Kelompok pengelola saat ini adalah pengurus yang sejak pertama berdiri belum pernah dilakukan regenerasi, padahal ada beberapa nama yang sudah sejak lama tidak aktif. Kaderisasi belum berjalan dengan baik yang terlihat dari tidak dilibatkannya pemuda dalam pengelolaan desa wisata. Keterlibatan pemuda hanya sebatas dilakukan pada kegiatan tertentu saja. Secara administrasi, pengelola desa wisata juga kurang mumpuni sehingga informasi tentang kegiatan wisata tidak tersalurkan dengan baik ke dinas-dinas terkait. Padahal pencatatan ke dinas terkait dapat dijadikan dasar bagi dinas untuk mengambil kebijakan terkait pembinaan atau program apa yang cocok untuk dilakukan di sebuah desa wisata. Berangkat dari kondisi tersebut maka peneliti mengambil rumusan masalah bagaimana kapasitas kelembagaan dalam pengelolaan Desa Wisata Brajan?

\section{Metode}

Penelitian ini adalah sebuah penelitian deskriptif dengan menggunakan pendekatan kualitatif. Tujuannya adalah untuk menjelaskan secara mendalam tentang segala temuan yang berkaitan dengan strategi penguatan kapasitas kelembagaan dalam pengelolaan desa wisata di Brajan.

Data yang diperlukan adalah data primer dan sekunder. Data primer didapatkan dari observasi dan wawancara. Observasi langsung dilakukan untuk melihat kondisi sehari-hari di Dusun Brajan, fasilitas yang tersedia, dan kegiatan pariwisata yang dijalankan. Selain itu juga akan dilakukan wawancara dengan pihak-pihak yang terkait seperti pengurus kelompok desa wisata, kepala dusun, pengurus kelompok pengelola desa wisata, pemuda setempat, dan masyarakat di Desa Brajan.

\section{Hasil dan Pembahasan}

Brajan sudah ditetapkan menjadi desa wisata sejak tahun 2006. Keberadaan Brajan sebagai desa wisata berbasis kerajianan bambu sudah sejalan dengan Peraturan Daerah Kabupaten Sleman No 11 Tahun 2015 tentang Rencana Induk Pembangunan Kepariwisataan Daerah Tahun 2015-2025. Di dalam Pasal 17 ayat 6 poin a disebutkan bahwa pengembangan kawasan Minggir dan sekitarnya sebagai kawasan wisata pertanian dengan cara mengembangkan kawasan Minggir sebagai kawasan wisata budidaya pertanian dan kerajinan hasil pertanian berbasis kearifan lokal. 
Kelembagaan menurut Awang (2005) merupakan sekumpulan nilai, norma, peraturan dalam suatu kumpulan orang yang digunakan untuk mencapai tujuan tersebut. Di Desa Wisata Brajan sudah berdiri sebuah lembaga pengelola yang bertugas untuk menjalankan kegiatan pariwisata di Brajan. Nilai-nilai yang dipegang oleh pengelola desa wisata di antaranya adalah nilai keindahan yang tercermin dari adanya kerja bakti rutin di dusun untuk menjaga kebersihan dan keindahan kawasan Brajan. Selain itu nilai kebaikan juga dipegang dalam berinteraksi dengan wisatawan yang tentu sosok asing bagi mereka. Hal ini tercermin dari keramahan dalam menyambut tamu, keinginan untuk memenuhi harapan dari wisatawan, dan kesopanan yang ditunjukkan kepada siapapun yang datang.

Horton (2003) mendefinisikan capacity development ini ke dalam beberapa hal seperti berikut:

1. Penguatan kapasitas adalah sebuah proses yang berjalan.

2. Penguatan kapasitas bertujuan untuk meningkatkan kemampuan organisasi untuk menjalankan fungsinya dan mencapai tujuannya.

3. Penguatan kapasitas meningkatkan kemampuan organisasi untuk belajar dan menyelesaikan permasalahan.

4. Penguatan kapasitas termasuk menciptakan kemampuan untuk menyelesaikan permasalahan hari ini dan permasalahan relevan yang dimungkinkan muncul di masa yang akan datang.

Horton mengidentifikasikan dua aspek untuk dapat melihat kapasitas organisasi yaitu kapasitas manajerial dan kapasitas pengelolaan sumber daya. Menurut Horton et al (2003), kapasitas organisasi bergantung pada manajemen yang dimilikinya. Manajemen ini merupakan soft capacities dari sebuah organisasi. Kegiatan manajemen dikelompokkan pada 3 (tiga) kelompok menurut Horton et al (2003) yaitu (1) manajemen proses dan program, (2) kepemimpinan strategis, serta (3) jejaring dan hubungan. Melihat pada pedoman pembentukan Kelompok Sadar Wisata yang dikeluarkan oleh Kementerian Pariwisata pada tahun 2012, maka dalam sebuah kepengurusan desa wisata perlu diterjemahkan dalam suatu struktur organisasi yang sistematis supaya setiap pihak dapat mengetahui tugas dan wewenang masing-masing. Jika dibuat pada bagan, maka struktur kepengurusan Desa Wisata Brajan adalah seperti dalam Gambar 1.

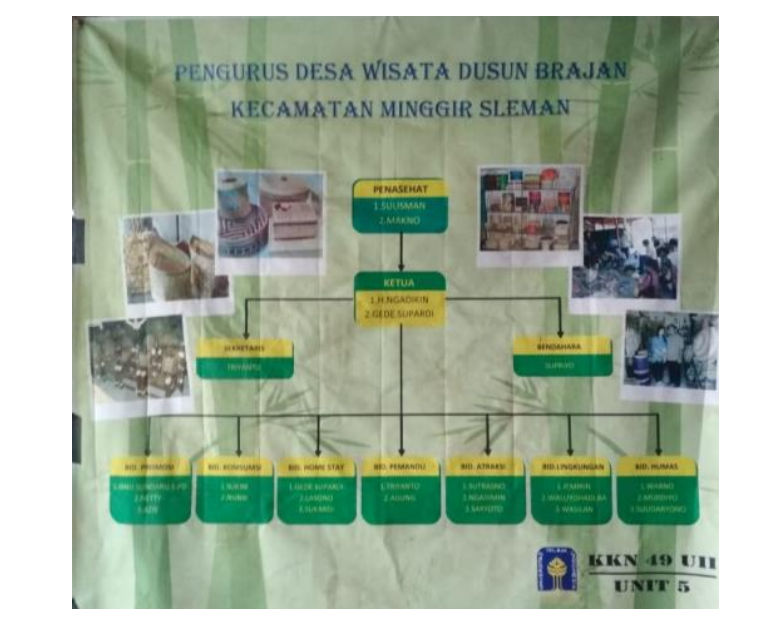

Gambar 1. Struktur Organisasi Pengurus Desa Wisata

(Sumber: Dokumentasi Peneliti, 2019) 
Dari struktur di atas sudah jelas adanya pembagian tugas dari kelompok pengelola Desa Wisata Brajan. Untuk analisis lebih rinci maka kapasitas kelembagaan pengelola yang dilihat dari aspek manajemennya akan dijelaskan dalam tiga kelompok yaitu (1) kepemimpinan strategis, (2) manajemen proses dan program, serta (3) jejaring dan hubungan.

\section{Kepemimpinan Strategis}

Di Desa Wisata Brajan, kelompok pengelola dipimpin oleh Bapak NDK. Di dalam kesehariannya Bapak NDK bekerja sebagai pegawai di Universitas Muhammadiyah Yogyakarta. Kepemimpinan Bapak NDK dimulai sejak kelompok pengurus desa wisata ini berdiri. Sebagai seorang pemimpin, menurut Horton et al (2003) kapasitas yang harus dimiliki adalah:

1. Menilai dan menafsirkan kebutuhan dan peluang di luar organisasi

2. Menetapkan arah

3. Mempengaruhi dan menyelaraskan orang lain menuju tujuan bersama

4. Memotivasi dan mendorong untuk berkomitmen dan bertanggungjawab

Berdasarkan hasil wawancara dengan perwakilan pengurus yaitu Bapak LSN, Bapak SPY, Bapak TYT, dan Ibu SRD pola kepemimpinan Bapak NDK termasuk demokratis. Permasalahan yang terjadi dalam kegiatan wisata dikemukakan oleh para pengurus di dalam rapat pengurus dan akan dicarikan solusi bersama. Pada saat akan ada kunjungan maka pengurus selalu mengadakan rapat persiapan terkait atraksi apa saja yang akan disuguhkan dan pembagian tugasnya. Di dalam rapat tersebut akan ditampung ide-ide kreatif tentang penerimaan tamu. Misalnya untuk penjemputan akan dibuat dengan konsep sepeda atau kereta mini, menu makanan yang akan disajikan, lokasi penerimaan tamu, dan agendanya seperti apa.

Dilihat dari kemampuan menetapkan arah dan tujuan, hingga saat ini Desa Wisata Brajan belum memiliki program kerja rutin maupun dokumen rencana pengembangan desa wisata. Keberadaan masterplan pengembangan desa wisata hanya berhenti pada tataran pembangunan infrastrukturnya saja, sementara untuk program kerja dan rencana pengembangan desa wisata ke depan belum tertuang dalam bentuk dokumen, semua masih berbentuk gagasan lisan yang seringkali dibahas dalam rapat pengurus. Perlunya dokumen program kerja penting supaya apa yang sudah dicanangkan dapat diketahui oleh seluruh pengurus dan tidak menjadi wacana yang mudah terlupakan karena tidak ada catatannya. Sehingga selama ini proses kegiatan wisata hanya berlangsung sebagai sebuah kebiasaan saja. Ketika ada tamu akan berkunjung, pengurus akan rapat persiapan, kemudian dilakukanlah kegiatan kunjungan. Secara administrasi juga tidak terkontrol sehingga pencatatan kunjungan tidak terorganisir, keberadaan notulen rapat juga hilang padahal hasil rapat dapat digunakan sebagai bahan penyusunan kebijakan selanjutnya.

Sementara untuk kemampuan memotivasi dan mendorong orang lain untuk bertanggungjawab pada pekerjaannya, belum cukup terlihat karena pada kenyataannya dari seluruh pengurus yang namanya terdaftar secara resmi, ada beberapa yang tidak aktif. Hal ini diakui sendiri oleh Bapak NDK bahwa seksi-seksi yang ada di bawah kepemimpinannya masih belum bekerja secara maksimal. Seluruh pengurus yang diwawancara juga mengatakan hal serupa, bahwa ada beberapa pengurus yang tidak aktif. Namun Bapak NDK konsisten untuk 
menghadirkan dirinya sebagai pemimpin yang terlihat dari kehadirannya di setiap kunjungan rombongan yang ada sekalipun memiliki pekerjaan utama sebagai pegawai swasta.

Di dalam upaya untuk mengarahkan orang lain untuk menuju tujuan bersama diperlihatkan dalam setiap rapat pengurus dan melalui upayanya untuk menjadi narahubung dari desa wisata kepada calon wisatawan. Setiap ada wisatawan yang akan berkunjung maka Bapak NDK akan langsung memberikan informasi kepada pengurus dan mengumpulkan pengurus dalam sebuah rapat. Di dalam rapat akan ditentukan tentang sistem penerimaan kunjungan yang akan dilakukan. Perannya akan selalu mengarahkan selama proses persiapan agar pada saat kunjungan semua dapat berjalan sesuai dengan rencana. la mampu untuk mengkoordinasikan pengurus yang masih tersisa aktif untuk bergerak agar Desa Wisata Brajan dapat terus berkembang. Kemampuannya bernegosiasi juga dilakukan dengan bekerjasama dengan stakeholder lain seperti pemerintah, universitas, dan swasta untuk memberikan bantuan yang sesuai dengan apa yang dibutuhkan oleh desa wisata ini.

\section{Manajemen Proses dan Program}

Menurut Horton et al (2003) dalam melihat kapasitas organisasi dari segi program dan proses ada 4 (empat) macam kapasitas yaitu:

1. Manajemen siklus proyek

2. Perencanaan dan perumusan program

3. Pemantauan dan evaluasi

4. Pelaporan

Berkaca pada empat kapasitas menurut Horton (2003) tersebut, pengelola desa wisata Brajan sendiri berdasarkan hasil penelitian ternyata belum memiliki program kerja tahunan ataupun rencana jangka panjang maupun pendek terhadap kegiatan pariwisatanya maupun siklus evaluasi dan pelaporan dari setiap program kerjanya. Adapun masterplan yang dimaksud oleh Bapak NDK adalah masterplan pengembangan kawasan wisata di Brajan periode tahun 20162020 seperti tertera dalam Gambar 2.

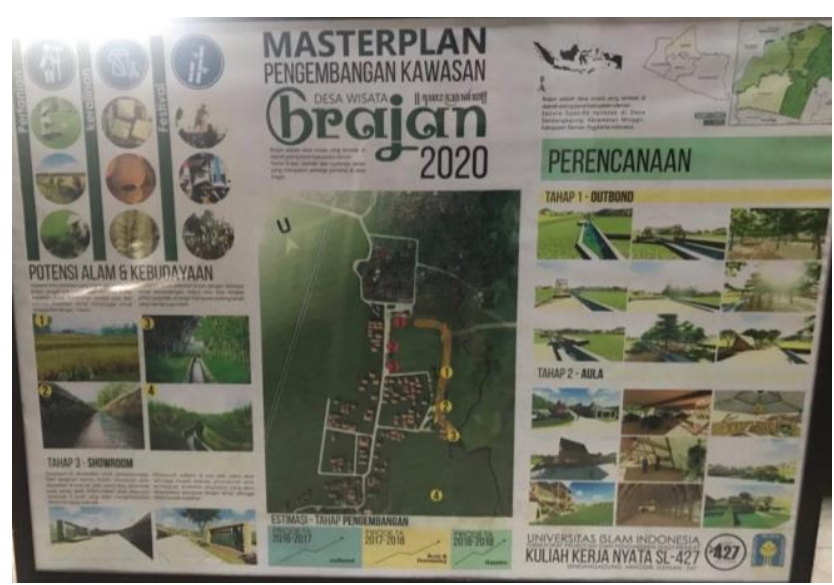

Gambar 2. Masterplan Pembangunan Desa

(Sumber: Dokumentasi Peneliti, 2019)

Masterplan tersebut dibuat bekerjasama dengan mahasiswa Universitas Islam Indonesia yang sedang melaksanakan KKN di Desa Wisata Brajan pada tahun 2016. Di dalam masterplan 
tersebut dibuat perencanaan pengembangan desa wisata secara fisik dengan alur sebagai berikut:

1. Periode 2016-2017 akan dibangun sarana outbond

2. Periode 2017-2018 akan dibangun aula dan homestay

3. Periode 2018-2019 akan dibangun gazebo yang juga berfungsi sebagai showroom

Saat ini di tahun 2019, yang artinya merupakan periode terakhir dari masterplan tersebut ada rencana yang sudah tercapai yaitu adanya homestay. Keberadaan homestay ini tersebar di rumah-rumah warga. Menurut Bapak LSN selaku pengurus bidang homestay, syarat sebuah rumah dapat dijadikan homestay adalah (1) bersih, (2) tersedia toilet yang memadai, dan (3) ada kamar kosong yang dapat digunakan. Sementara untuk pembangunan sarana outbond baru dikerjakan di tahun 2019 ini dengan sistem gotong royong. Namun sayangnya masterplan tersebut hanya berhenti pada proses pembangunan fisik saja, tidak ada program kerja tahunan ataupun target pembangunan yang berjangka waktu. Untuk perumusan program sendiri dilakukan setiap akan ada kunjungan saja, apalagi jika penerimaan kunjungan dari rombongan yang berjumlah banyak.

\section{Jejaring dan Hubungan dengan Stakeholder}

Horton et al (2003) menyatakan bahwa salah satu kapasitas operasional yang harus dimiliki terkait dengan relasi stakeholder adalah kemampuan untuk membangun hubungan baik dengan mitra. Di Desa Wisata Brajan sendiri saat ini sudah menjalin kerjasama dengan beberapa pihak sebagaimana dirangkum dalam Tabel 2.

Tabel 2. Daftar Kerjasama

\begin{tabular}{|c|c|c|}
\hline No & Instansi & Bentuk Kerjasama \\
\hline 1 & PT. Jasa Raharja & $\begin{array}{ll}\text { - } & \text { Pembangunan gapura } \\
\text { - } & \text { Bantuan modal pendirian taman bunga }\end{array}$ \\
\hline 2 & Universitas Islam Indonesia & $\begin{array}{l}\text { - } \text { Ditetapkan sebagai desa binaan } \\
\text { - Pemberian seperangkat komputer dan jaringan internet } \\
\text { - } \quad \text { Pelatihan }\end{array}$ \\
\hline 3 & Universitas Amikom Yogyakarta & - Pelatihan dalam penataan lingkungan \\
\hline 4 & Universitas Sanata Dharma & $\begin{array}{l}\text { - Pelatihan kepada pengurus dan pengrajin di bidang } \\
\text { manajemen desa wisata }\end{array}$ \\
\hline 5 & Pemerintah Kabupaten Sleman & $\begin{array}{l}\text { - Pengikutsertaan dalam kegiatan pelatihan-pelatihan } \\
\text { maupun dikirim sebagai trainer untuk kegiatan yang } \\
\text { diselenggarakan Dinas Pariwisata misalnya pelatihan } \\
\text { pemasaran desa wisata, pelatihan untuk pemandu } \\
\text { wisata, pelatihan desain kerajinan, dan pelatihan } \\
\text { manajemen pengelolaan desa wisata. }\end{array}$ \\
\hline
\end{tabular}

(Sumber: Analisis Data Primer dan Sekunder, 2019)

Kerjasama-kerjasama sebagaimana disebutkan dalam Tabel 2 didapatkan melalui perantara Bapak SLM selaku kepala dusun, penggagas desa wisata, sekaligus penasehat pengurus. Bapak SLM yang melakukan penandatanganan perjanjian dengan UII dan PT. Jasa Raharja tersebut sehingga kerjasama dapat berlangsung hingga kini. Selain Bapak SLM, orang yang memiliki peran penting dalam kegiatan kerjasama dengan pihak eksternal adalah Bapak NDK. Untuk pengajuan bantuan biasanya akan dibuat proposal terlebih dahulu. Proposal pengajuan ini disusun oleh Bapak TYT selaku sekretaris dan juga dibantu oleh pemuda. Proposal ini yang menjadi dasar pengajuan penawaran kerjasama. Kerjasama dengan pemerintah dibangun 
melalui relasi yang baik antara pengelola desa wisata dengan Pemerintah Kabupaten Sleman berupa pelatihan-pelatihan yang diberikan oleh pemerintah kepada pengurus desa wisata.

\section{Kapasitas Pengelolaan Sumber Daya}

Horton (2003) mengungkapkan bahwa penting bagi organisasi untuk dapat mengelola sumber daya yang dimilikinya. Di dalam bukunya Horton (2003) mengungkapkan bahwa sumber daya yang dimaksud adalah sumber daya manusia, infrastruktur, keuangan, dan teknologi.

\section{Kapasitas Pengelolaan SDM}

Sumber daya manusia merupakan salah satu aspek paling penting dalam berjalannya suatu organisasi. Hal tersebut dikarenakan berjalannya organisasi digerakkan oleh sumber daya manusia yang ada di dalamnya. Saat ini ada 23 orang yang terdaftar sebagai pengurus desa wisata. Dari 23 orang tersebut terdapat 2 orang yang merangkap jabatan yaitu Bapak Gede Supardi dan Bapak TYT. Berdasarkan hasil wawancara, sosok yang sangat berperan dalam berjalannya organisasi adalah Bapak SLM, Bapak NDK, Bapak Gede Supardi, dan Bapak TYT. Keempat orang tersebut yang selalu aktif menggerakkan terutama ketika akan ada kunjungan ke desa wisata. Dari jumlah pengurus yang terdaftar, sudah banyak yang tidak aktif lagi. Tidak aktifnya pengurus tersebut tentu menjadikan organisasi tidak berjalan secara maksimal karena ada beberapa sektor yang berjalan kurang baik. Sampai saat ini belum ada daftar resmi tentang pengurus yang benar-benar masih aktif. Alasan di balik tidak aktifnya pengurus ini beragam di antaranya karena kesibukan pekerjaan dan pindah tempat tinggal. Belum ada kaderisasi lebih lanjut untuk menyelesaikan permasalahan ini.

Setelah dilakukan wawancara dan observasi kemudian muncul fakta bahwa masyarakat yang non pengurus juga sering terlibat dalam pengelolaan, seperti yang terjadi pada Ibu SRD. Ibu SRD tidak terdaftar sebagai pengelola desa wisata, namun pada kenyataannya Ibu SRD cukup aktif dalam kegiatan kunjungan.

Grindle (1997) menyebutkan bahwa salah satu dimensi dalam pengembangan kapasitas adalah dimensi pengembangan sumber daya manusia. Fokus yang dibahas oleh Grindle pada dimensi pengembangan sumber daya manusia adalah adanya tenaga teknis yang profesional. Pasokan tenaga teknis profesional tersebut diperoleh dengan adanya pelatihan, sistem gaji, situasi kerja, dan perekrutan. Di kelompok pengelola Desa Wisata Brajan jika dianalisis berdasarkan teori dari Grindle maka dapat dijelaskan sebagai berikut:

\section{Pelatihan}

Pelatihan sangat diperlukan dalam rangka meningkatkan kompetensi pengurus dalam menjalankan proses bisnisnya. Di Brajan, pelatihan sudah sering dilakukan. Berdasarkan hasil penelitian, pelatihan yang paling sering diberikan adalah di bidang pengembangan kerajinan bambu seperti pengembangan desain dan teknik mewarnai.

\section{Sistem Gaji}

Di dalam sistem pengelolaan keuangan di Desa Wisata Brajan masih berjalan secara sangat sederhana. Tidak ada penggajian tetap karena menurut Bapak NDK selaku ketua, kelompok pengelola desa wisata ini belum profit oriented. Penghasilan dari desa wisata memang bukan penghasilan pokok dari masyarakat. Di luar kunjungan 
masyarakat tetap bekerja membuat kerajinan bambu dan mendapatkan uang untuk membiayai kebutuhan sehari-hari dari hasil penjualan kerajinan itu.

Pembagian keuntungan bagi pengurus ketika ada kunjungan pun jumlahnya tidak tetap, namun bagi pengurus yang berhasil membawa wisatawan akan mendapatkan uang tambahan. Hal ini sebenarnya cukup baik sebagai bentuk penghargaan lebih terhadap pengurus yang memang terlibat dalam kunjungan dan pengurus yang berhasil negosiasi untuk membawa wisatawan.

\section{Situasi Kerja}

Berdasarkan hasil wawancara dan observasi, pola kerja di kelompok pengelola ini bersifat kekeluargaan. Pengurus aktif sampai sekarang merupakan kesadaran sendiri dan tercipta suasana demokratis dalam setiap pengambilan keputusan. Pembahasan tentang konflik internal dapat diungkapkan di setiap rapat persiapan maupun rapat evaluasi. Pola kerja dari setiap pengelola juga tidak mengganggu pekerjaan utama karena pekerjaan utama sebagian besar pengelola memang bergerak di industri kerajinan. Sementara untuk pengelola yang memiliki pekerjaan utama di luar industri kerajinan maka akan mengatur jadwal dari kantor.

\section{Perekrutan}

Sistem perekrutan pada kelompok pengelola desa wisata berdasarkan penunjukan dan kesepakatan dengan individu tersebut. Tidak ada seleksi yang berarti karena organisasi ini adalah hasil swadaya masyarakat dan tidak berorientasi pada profit. Perekrutan dilakukan sejak kelompok pertama kali didirikan hingga saat ini belum pernah ada perekrutan kembali atau regenerasi. Tidak ada standar kompetensi khusus yang ditetapkan sebagai syarat bergabung menjadi pengurus dan tidak ada perjanjian dalam kinerjanya.

\section{Pengelolaan Sumber Daya Infrastruktur, Keuangan, dan Teknologi}

Pengelolaan infrastruktur di Desa Wisata Brajan dikelola oleh Padukuhan Brajan. Bantuan dari pemerintah terkait infrastruktur seperti pembangunan saluran irigasi dan pengerasan jalan dilakukan melalui padukuhan selaku perwakilan pemerintah di level dusun. Alokasi yang didapatkan dari pemerintah itu yang diarahkan untuk mendukung kegiatan pariwisata. Namun untuk infrastruktur yang berasal dari bantuan pihak ketiga hasil kerjasama melibatkan pula pengelola desa wisata seperti pembangunan gapura dan pembangunan taman. Pembangunan gapura adalah hasil bantuan kerjasama antara pihak pengelola desa wisata dan Universitas Islam Indonesia.

Aspek kapasitas mengelola sumber daya keuangan berdasarkan hasil penelitian pengelola masih melakukan pembukuan dengan pencatatan sederhana dalam sebuah buku besar. Untuk pencatatan keuangan sendiri dibagi menjadi beberapa penanggungjawab. Penerimaan kotor dikelola oleh ketua pengelola yaitu Bapak NDK dan kemudian dibagi ke dalam pengeluaran-pengeluaran yang diperlukan. Pembagian tersebut dilakukan dalam rapat evaluasi yang dilaksanakan setiap selesai kunjungan. Kemudian setelah bersih baru masuk ke kas bendahara yaitu Bapak SPY. Bendahara hanya mengelola uang bersih sisa kegiatan saja, tidak mengelola uang hasil kerjasama ataupun bantuan. Uang yang dikelola oleh bendahara digunakan untuk mendukung operasional pengelola seperti pembuatan seragam pengurus. Untuk kendala yang dihadapi adalah keterbatasan pengetahuan bendahara mengenai 
pembukuan sehingga hanya melakukan pembukuan secara manual, tidak dilakukan dalam komputer. Selain karena keterbatasan pengetahuan juga keterbatasan sarana prasarana yang dimiliki. Tidak ada komputer untuk menyimpan data.

Terkait dengan sumber daya teknologi, saat ini pengelola sebagian besar merupakan generasi yang sudah berusia 40 tahun ke atas dan tidak banyak yang mampu mengoperasikan komputer dengan baik. Hal-hal yang berkaitan dengan teknologi akan dimintakan bantuan kepada pemuda untuk mengelolanya. Keberadaan seperangkat komputer dan jaringan internet yang saat ini diletakkan di rumah Bapak SLM dimanfaatkan untuk mengelola website desa wisata dan dilakukan oleh Saudara DNG dan Saudari NT. Namun pemanfaatannya juga belum intens karena terganjal kesibukan dari pengelola.

\section{Partisipasi}

Desa Wisata Kerajinan Bambu Brajan dikembangkan dengan pendekatan pariwisata berbasis masyarakat. Berdasarkan hasil kajian pengembangan desa wisata dari Dinas Pariwisata Provinsi Daerah Istimewa Yogyakarta, pendekatan tersebut melibatkan masyarakat baik dalam proses pengambilan maupun dalam pembagian pendapatan.

Pendekatan ini diharapkan dapat membuka lapangan kerja, mengurangi angka kemiskinan, dan melestarikan lingkungan sosial budaya. Salah satu aspek penting dalam pendekatan tersebut adalah adanya partisipasi dari masyarakat. Partisipasi menurut Suyatno dan Suparja (2003) adalah bentuk keterlibatan mental dan emosional seseorang dalam setiap kelompok yang mendorong mereka untuk ikut serta menyumbangkan kemampuan dalam mencapai tujuan kelompok serta ikut bertanggungjawab atas tujuan kelompok tersebut. Di dalam penelitian ini juga mencoba untuk melihat partisipasi masyarakat di Brajan yang dilihat dari sudut pandang pengurus, pemuda, dan masyarakat desa yang tidak tergabung dalam kepengurusan desa wisata.

\section{Pemuda}

Penelitian ini mencoba melihat dari sisi pemuda untuk melihat kemungkinan regenerasi dari Desa Wisata Brajan. Regenerasi ini dibutuhkan mengingat seluruh pengurus dan perajin di Desa Wisata Brajan merupakan sebagian besar orang tua sehingga peran pemuda dibutuhkan agar eksistensi Desa Wisata Brajan tetap terjaga. Di Dusun Brajan sebenarnya ada sebuah organisasi karang taruna namun sudah sejak lama tidak aktif. Sebab dari tidak aktifnya karang taruna adalah banyaknya pemuda yang sudah merantau untuk bekerja sementara pemuda yang masih tinggal di Dusun Brajan sendiri juga sudah sibuk dengan pekerjaan dan sekolahnya. Menurut hasil wawancara dengan Bapak NDK, Bapak SLM, dan Saudara DNG, minat pemuda desa untuk melanjutkan industri kerajinan bambu sangat minim. Mereka lebih memilih bekerja di pabrik, retail, guru, dan pekerjaan lain yang dianggap lebih menjanjikan.

\section{Pengurus}

Penelitian ini juga berusaha melihat partisipasi dari pengurus kelompok desa wisata sendiri dalam kegiatan yang dijalankan. Partisipasi yang akan dilihat berdasarkan pendapat dari Mardikantor dan Purwoko (2017) ada 4 (empat) tahapan yaitu: 


\section{a. Partisipasi dalam Pengambilan Keputusan}

Di dalam pengambilan keputusan sudah nampak adanya partisipasi dari pengurus yang terlihat dari adanya proses musyawarah mufakat dalam rapat pengaturan kunjungan yang dilakukan. Berdasarkan hasil wawancara dengan pengurus, setiap keputusan yang diambil didiskusikan terlebih dahulu sehingga setiap kebijakan yang akan diambil sudah diketahui dan disetujui oleh pengurus. Pengurus bebas untuk menyampaikan usulan dan ide pada rapat yang biasanya diselenggarakan setiap adanya kunjungan.

b. Partisipasi dalam Implementasi

Di dalam implementasi seperti misalnya ketika penerimaan kunjungan, kerjasama dengan pihak eksternal, pengembangan atraksi wisata, atau keikutsertaan lomba maka pengurus biasanya berpartisipasi dengan mengambil peran misalnya sebagai instruktur, menyiapkan konsumsi, atau mengkoordinir homestay. Misalkan dalam keikutsertaan dalam lomba, pengurus terlibat dalam penyiapan aspek-aspek yang dinilai dan kehadiran pada saat penilaian. Partisipasi dalam kerjasama dengan pihak eksternal terlihat dari keterlibatan dalam pengelolaan taman bunga yang merupakan bantuan dari PT. Jasa Raharja.

c. Partisipasi dalam Manfaat

Partisipasi ini ditandai dengan keikutsertaan dalam menerima manfaat dari kebijakan yang diambil. Partisipasi ini sudah terlihat dari beberapa aspek, misalnya dari aspek keuangan maka pengurus merasakan manfaat dari adanya sistem bagi hasil dan honorarium sebagai instruktur. Ada pula pengurus yang kemudian membuka usaha warung kelontong di area desa wisata. Manfaat lain yang mereka terima adalah secara tidak langsung mempromosikan usaha yang dijalankan di bidang kerajinan bambu sehingga bisa memperluas pasar penjualan.

d. Partisipasi dalam Evaluasi

Partisipasi dalam evaluasi tercermin dari adanya rapat evaluasi setiap akhir kunjungan yang memungkinkan pengurus untuk menyampaikan keluhan, hambatan, dan saran dalam kegiatan yang akan diselenggarakan ke depannya.

\section{Masyarakat Dusun}

Kegiatan wisata di Brajan tidak hanya menyangkut pada pengelola saja, melainkan masyarakat Brajan sendiri juga terlibat dalam kegiatan wisata. Keterlibatan masyarakat desa selain mereka sebagai obyek dalam wisata juga sebagai subyek yaitu pelaku wisata. Menurut Suyatno dan Suparja (2003), partisipasi adalah bentuk keterlibatan mental dan emosional seseorang dalam setiap kelompok yang mendorong mereka untuk ikut serta menyumbangkan kemampuan dalam mencapai tujuan kelompok serta ikut bertanggungjawab atas tujuan kelompok tersebut. Jika masyarakat desa secara mental dan emosional sudah terlibat, maka akan timbul rasa memiliki terhadap kegiatan wisata yang berlangsung di desanya. Berdasarkan hasil wawancara dengan masyarakat Dusun Brajan yang tidak tergabung dalam kelompok pengurus, keterlibatan berbentuk sebagai berikut:

a. Sebagai Instruktur Pelatihan

b. Aktif dalam kegiatan gotong royong pembangunan sarana prasarana wisata 

c. Membantu keperluan kunjungan
d. Menyambut wisatawan dengan ramah

\section{Kesimpulan}

Berdasarkan hasil penelitian yang telah dilaksanakan di Desa Wisata Brajan, maka dapat ditarik kesimpulan sebagai berikut:

1. Kapasitas kelembagaan pengelola Desa Wisata Brajan dari aspek manajemen dapat dilihat dari kepemimpinan strategis, manajemen program dan proses, serta jejaring dan hubungan dengan stakeholder. Kepemimpinan strategis di pengelola masih kurang baik, sementara dari manajemen program dan proses juga masih kurang baik, namun dari segi mengelola jejaring dan hubungan sudah baik.

2. Kapasitas kelembagaan pengelola Desa Wisata Brajan dilihat dari aspek pengelolaan sumber daya manusia masih kurang baik. Begitu pula dilihat dari pengelolaan sumber daya infrastruktur, teknologi, dan sumber daya keuangan juga kurang baik.

3. Kapasitas pengelola Desa Wisata Brajan dilihat dari partisipasi pengurus masih kurang karena banyaknya pengurus yang tidak aktif, dari segi pemuda masih kurang terlibat dalam kegiatan pengelolaan organisasi, dari masyarakat keterlibatan nampak dari keterlibatan dalam gotong royong maupun sebagai instruktur dalam pelatihan.

\section{Daftar Pustaka}

Awang, San Afri, 2005, Manajemen Hutan Rakyat Kolaboratif di Tingkat Kawasan: Petani, Ekonomi, dan Konservasi, Aspek Penelitian dan Gagasan, Yogyakarta: Debut Press.

Grindle, Merille S, 1997, Getting Good Government Capacity Building in The Public Sectors of Develiping Countries, Cambridge: Harvard University Press.

Horton, D., Alexaki, A., Bennett-Lartey, S., Brice, K N., Campilan, D., Carden., F., Silva, J S., Duong, L T., Khadar, I., Boza, A M., Muniruzzaman, I K., Perez, Jocelyn., P., Chang, M S., Vernooy, R., dan Watts, J, 2003, Evaluating Capacity Development: Experience From Research and Development Organizations Around The World, Wagenigen: Isnar.

Peraturan Daerah Kabupaten Sleman No 11 Tahun 2015 tentang Rencana Induk Pembangunan Kepariwisataan Daerah Tahun 2015-2025. 